\title{
Understanding Cross-Border Conflict in Post-Soviet Central Asia: The Case of Kyrgyzstan and Tajikistan
}

\section{Kemel Toktomushev}

University of Central Asia, Bishkek, Kyrgyzstan, http://www.ucentralasia.org

\begin{abstract}
Despite the prevalence of works on the 'discourses of danger' in the Ferghana Valley, which re-invented post-Soviet Central Asia as a site of intervention, the literature on the conflict potential in the cross-border areas of Kyrgyzstan and Tajikistan is fairly limited. Yet, the number of small-scale clashes and tensions on the borders of the Batken and Isfara regions has been growing steadily. Accordingly, this work seeks to contribute to the understanding of the conflict escalations in the area and identify factors that aggravate tensions between the communities. In particular, this article focuses on four variables, which exacerbate tensions and hinder the restoration of a peaceful social fabric in the Batken-Isfara region: the unresolved legacies of the Soviet past, inefficient use of natural resources, militarization of borders, and lack of evidence-based policymaking.
\end{abstract}

Keywords: Central Asia, Kyrgyzstan, Tajikistan, Ferghana, conflict, borders.

\section{Introduction}

The significance and magnitude of violence and conflict potential in the contemporary Ferghana Valley has been identified as one of the most prevalent themes in the study of post-Soviet Central Asia. This densely populated region has been long portrayed as a site of latent inter-ethnic conflict. Not only is the Ferghana Valley a region, where three major ethnic groups-Kyrgyz, Uzbeks and Tajiks-co-exist in a network of interdependent communities, sharing buri- 
al sites, grazing grounds, and markets, but it is also a region where ethnic and political boundaries often do not coincide. ${ }^{1}$

Accordingly, soon after the demise of the Soviet Union, the Ferghana Valley was discursively cast as a volatile and crisis-ridden region prone to sectarian violence. Such discourses characterized post-Soviet Central Asia as a site of intervention, prompting the international community to enter the region to mitigate conflict potential and promote peaceful development. However, such interventions brought little harmony to fractured communities, as they were detached from the local context, simulated 'bottom-up' peacebuilding and were overly technical and procedural. ${ }^{2}$ Moreover, apart from misdiagnosing the causes of the conflicts, international aid agencies inadvertently supported the strengthening of authoritarianism in Central Asia, which generated the real grievances and anxieties in the region. ${ }^{3}$ Surprisingly, many academic and policy-oriented works continued to stress the need for a change that should come from the international community without questioning local realities.

In this regard, this article seeks to contribute to the mitigation of violent conflict and promotion of peaceful development in the Ferghana Valley through the advancement of an evidence-based approach to understanding conflict. This work attempts to identify drivers of conflict escalation in the cross-border areas of Kyrgyzstan and Tajikistan, Batken and Isfara respectively, which have long been the scenes of periodic conflicts, involving civilians, security forces and state officials.

\section{Etymology of Conflict}

Understanding different theoretical perspectives of conflict is important both for analyzing the phenomenon and for developing respective mechanisms and responses. After the end of the Cold War, conflicts were no longer perceived as resultant from ideological standpoints, but rather as a struggle of intrinsic antagonisms. New studies of conflicts favored interpretations of conflict, which underlined primordial ethnic, cultural or religious differences and which called for international therapeutic interventions to contain violence and instability. ${ }^{4}$ Such "interventionism" was justified by the distorted representation of weak

1 Madeleine Reeves, "Locating Danger: Konfliktologiia and the Search for Fixity in the Ferghana Valley Borderlands," Central Asian Survey 24, no. 1 (2005): 67-81.

2 John Heathershaw, "Review of the book Conflict Transformation in Central Asia: Irrigation Disputes in the Ferghana Valley, by Christine Bichsel," Central Asian Survey 29, no. 1 (March 2010): 131-142.

3 Christine Bichsel, "In Search of Harmony: Repairing Infrastructure and Social Relations in the Ferghana Valley," Central Asian Survey 24, no. 1 (March 2005): 5366.

4 Daniela Nascimento, "The (In)Visibilities of War and Peace: A Critical Analysis of Dominant Conflict Prevention and Peacebuilding Strategies in the Case of Sudan," International Journal of Peace Studies 16, no. 2 (Winter 2011): 43-57. 
states as failures of the modernity project. ${ }^{5}$ According to this view, the result of this failure was the growth of failed states, which laid the foundation for the proliferation of 'new wars' characterized by new forms of warfare, identity politics, decentralized violence and a globalized war economy. ${ }^{6}$

These 'new wars' construct new sectarian identities that undermine a sense of shared community and are usually difficult to end, because there is often no single cause of the conflict. ${ }^{7}$ Warring parties have vested interests in the continuation of violence for various reasons, and the advocates of this 'new wars' hypothesis identified 'greed' or economic motives as the primary driver of conflict. Using a data set of civil wars over the period of 1960-1999, Paul Collier and Anke Hoeffler developed econometric models to predict the outbreak of civil conflict. ${ }^{8}$ They concluded that a model, which focused on the opportunities and economic conditions for rebellion, performed well, whereas grievances, such as ethnic and religious divisions within a community, added little explanatory power. These findings provoked further the "greed versus grievance" debate on the causes of conflict.

Although the economic agendas approach has revealed a new dimension of conflict, many observers were unconvinced that 'new wars' were indeed 'new' at all..$^{9}$ They argued that the role of economic factors cannot be easily isolated from other motivations, which lead to violence, and thus a range of motivations, including the nature of grievances, and their mutual interactions needs to be examined. ${ }^{10}$ In this context, despite being considered dated, Edward Azar's theory of protracted social conflict ${ }^{11}$ may also be useful to the understanding of contemporary conflict dynamics. Azar identified four variables, which are responsible for the transformation of non-conflictual situations into conflictual ones: communal content, human needs, government and the state's role, and

5 Mark Duffield, Global Governance and the New Wars: The Merging of Development and Security (London: Zed Books, June 2001); Christine Bichsel, Conflict Transformation in Central Asia: Irrigation Disputes in the Ferghana Valley (Abingdon, Oxon \& New York: Routledge, 2009); Nascimento, "The (In)Visibilities of War and Peace."

6 Mary Kaldor, New \& Old Wars: Organized Violence in a Global Era (Cambridge: Polity Press, 1999); Nascimento, "The (In)Visibilities of War and Peace."

7 Preeti Patel, "Causes of Conflict," in Conflict and Health, ed. Natasha Howard, Egbert Sondorp, and Annemarie ter Veen (Maidenhead: Open University Press, 2012), 5-13.

8 Paul Collier and Anke Hoeffler, "Greed and Grievance in Civil War," Oxford Economic Papers 56, no. 4 (October 2004): 563-595.

9 Stathis N. Kalyvas, "'New' and 'Old' Civil Wars: A Valid Distinction?" World Politics 54, no. 1 (October 2001): 99-118; Mats Berdal, "How 'New' Are 'New Wars'? Global Economic Change and the Study of Civil War," Global Governance 9, no. 4 (OctoberDecember 2003): 477-502.

10 Berdal, "How 'New' Are 'New Wars'?; David Keen, "Greed and Grievance in Civil War," International Affairs 88, no. 4 (2012): 757-77.

11 Edward E. Azar, The Management of Protracted Social Conflict: Theory and Cases (Hampshire: Dartmouth Publishing Company, April 1990). 
international linkages. As Oliver Ramsbotham ${ }^{12}$ underlined, policy recommendations from an 'economic agenda' approach do not significantly differ from those advanced by Azar, which are the importance of managing ethnic dominance, countering a lack of economic opportunity, remedying government inability to protect minorities and handling the influence of diasporas.

Based on these issues, Paul Rogers ${ }^{13}$ identified three probable trends of broad contemporary conflicts. The first arises from human migration through social, economic and environmental motives. Increased nationalist tendencies and cultural conflict may surface in the most vulnerable communities within the recipient regions of relative wealth. The second trend is a competitive and violent response of the disempowered within and between states. The third trend points to environmental and resource conflicts over issues such as fresh water, food or fossil fuels, whether local or regional.

The latter trend has been long attributed to the region of Central Asia, as many observers forecasted a fierce struggle in the Ferghana Valley over access to and use of limited natural resources. They predicted that unsatisfied human needs and porous borders would aggravate this competition and divide national communities along the region's ethnic lines.

\section{The Ferghana Valley}

The Ferghana Valley is a large diamond-shaped flatland spread in the heart of Central Asia across Southern Kyrgyzstan, Northern Tajikistan and Eastern Uzbekistan. Surrounded by extensive mountains of the Kuramin, Chatkal, Ferghana, Alai, and Turkestan ranges and roughly defined by the basins of the Syr Darya river, the 22,000-square-kilometre valley is distinguished by its agricultural fertility, the principal crops being cotton, rice, wheat, fruits, and vegetables.

The first signs of irrigated agriculture dated back to the late Bronze Age, and this agricultural productivity turned the Ferghana Valley into one of the most densely populated regions in the world. ${ }^{14}$ With a population of nearly 12-15 million, the valley accounts for approximately one fifth of Central Asia's total population. Thus, as Frederick Starr ${ }^{15}$ underlined, whatever will happen in the Ferghana Valley will directly affect the economic, political and religious spheres of all three states - Kyrgyzstan, Tajikistan and Uzbekistan.

12 Oliver Ramsbotham, "The Analysis of Protracted Social Conflict: A Tribute to Edward Azar," Review of International Studies 31, no. 1 (January 2005): 109-126, 123.

13 Paul Rogers, "Peace Studies," in Contemporary Security Studies, ed. Alan Collins (Oxford: Oxford University Press, 2007), 35-52.

14 Abdukakhor Saidov, Abdulkhamid Anarbaev, and Valentina Goriyacheva, "The Ferghana Valley: The Pre-Colonial Legacy, in Ferghana Valley: The Heart of Central Asia, ed. S. Frederick Starr, Baktybek Beshimov, Inomjon I. Bobokulov, and Pulat Shozimov (New York: M.E. Sharpe, 2011), 3-28.

15 S. Frederick Starr, "Introducing the Ferghana Valley," in Ferghana Valley, xii. 
Few were surprised, when the densely populated Ferghana Valley reemerged after the demise of the Soviet Union as a fundamentally unstable zone that was prone to violent inter-ethnic conflict. Ample academic and journalistic literature has surfaced to advise on fault lines in Central Asia. These works indicated that the valley needs to be 'calmed,' because it is a vulnerable area, where "new violence is likely, indeed, almost certain." ${ }^{16}$ While differing in nuances, the proponents of 'calming' the valley argued that the potential for conflict stemmed from a vast array of factors, including poverty, overpopulation, unemployment, ecological crises, ethnic fragmentation, drug trafficking, nationalism, corruption, authoritarianism, Muslim fundamentalism and even the conspirological engagement of third parties. ${ }^{17}$

While most of such 'catastrophizing' writings ${ }^{18}$ failed to demonstrate the existence of violent threats in the region and link the magnitude of predictions to the paucity of supporting evidence, ${ }^{19}$ what this literature succeeded in was re-inventing the Ferghana Valley as a site of intervention. As Christine Bichsel ${ }^{20}$ summarized, distinctly 'agentive' in nature, these works described a state of affairs in Central Asia requiring action to avert the dire consequences awaiting the region without external engagement, and calling on international aid agencies to swiftly take up those recommendations to mitigate perceived conflict. Quite often, those researchers, development agencies and experts claimed both a privileged relationship to understanding the reality in Central Asia and an implied obligation to cure the ills that can be seen from their privileged positions. $^{21}$

16 Senator Sam Nunn, Barnett R. Rubin, and Nancy Lubin, eds., Calming the Ferghana Valley: Development and Dialogue in the Heart of Central Asia (Preventive Action Reports, V. 4) (New York: The Century Foundation Press, December 1999), xvi.

17 Nunn, Rubin, and Lubin, Calming the Ferghana Valley; Anara Tabyshalieva, The Challenge of Regional Cooperation in Central Asia: Preventing Ethnic Conflict in the Ferghana Valley (Washington, DC: United States Institute of Peace, 1999); Randa Slim, "The Ferghana Valley: In the Midst of a Host of Crises," in Searching for Peace in Europe and Eurasia: An Overview of Conflict Prevention and Peacebuilding Activities, ed. Paul van Tongeren, Hans van de Veen, and Juliette Verhoeven (Boulder: Lynne Rienner, February 2002), 489-515; Aleksandr Osipov, "Ferghanskiye sobitiya 1989 goda: Konstruirovaniye etnicheskogo konflikta (The Ferghana Events of 1989: Construction of Ethnic Conflict)," in Ferghanskaya dolina: Etnichnost, etnicheskiye processi, etnicheskiye konflikty (Ferghana Valley: Ethnic processes, ethnic conflicts), ed. Sergei Abashin and Valentin Bushkov (Moscow: Nauka, 2004), pp. 164-223; Igor Rotar, "Will the Fergana Valley Become a Hotbed of Destabilization in Central Asia?" Eurasia Daily Monitor 9, no. 180 (October 2012), https://jamestown.org/program/ will-the-fergana-valley-become-a-hotbed-of-destabilization-in-central-asia.

18 As described by Starr, "Introducing the Ferghana Valley," in Ferghana Valley, xiii.

19 Nick Megoran, "Calming the Ferghana Valley Experts," Central Asian Monitor 2000, no. 5 (2000): 20-25, 21.

20 Bichsel, Conflict Transformation in Central Asia.

21 Chad D. Thompson and John Heathershaw, "Discourses of Danger in Central Asia: Introduction," Central Asian Survey 24, no. 1 (March 2005): 1-4, 4. 
Henceforth, from the late 1990s international aid agencies advanced a wide range of conflict prevention activities in the Ferghana Valley, which included prejudice reduction and tolerance education projects, early warning systems, topic-focused cross-border cooperation initiatives, entrepreneurship courses, micro-lending programs, and border management trainings. ${ }^{22}$ Such aid was usually spearheaded along the tenets of promoting 'liberal peace' to the Global South with its focus on democratization and economic liberalization. ${ }^{23}$ Indeed, the 'magic trio' of the market, democracy and civil society emerged as development panaceas in the 1980 s to become a prescriptive solution to the problems of development in the 1990s. ${ }^{24}$ Interventions of this nature were linked directly to a particular conceptualization of conflict by international aid agencies. Most of the aid agencies assumed that conflict in Central Asia will erupt over scarce natural resources; that conflict parties will be divided along ethnic lines; and that economic underdevelopment, porous borders and unsatisfied human needs will lead to the violence.

While Western blueprint reforms failed at triggering the development of a pluralistic society and fostering democratic transformations in the region, a myriad of introduced conflict prevention initiatives exposed the notion that conflict in Central Asia, whether real or perceived, cannot be reduced to a single variable. Ultimately, as Nick Megoran underlined, many of the factors, which have triggered conflicts elsewhere in the world, are present in the Ferghana Valley, and thus the main goal of the researchers, aid agencies, governments, and local communities alike is to introduce the changes necessary to prevent conflicts. ${ }^{25}$

\section{Batken and Sughd}

Despite the prevalence of such 'catastrophizing' works about the Ferghana Valley, the literature on conflict potential in the Kyrgyz-Tajik border areas is limited. Yet, the number of small-scale clashes and tensions on these borders has been growing steadily. Constituting part of the Ferghana Valley, the Batken region is located in the southwest of Kyrgyzstan. The region was established as a seventh separate oblast of Kyrgyzstan on October 12, 1999, partially as a result of the incursions of militant pan-Islamist extremists into the Ferghana Valley. The region has the population of 492,600 and relies heavily on livestock and

22 Luigi De Martino, "Peace initiatives in Central Asia: An inventory," Situation Report (Geneva: Cimera, 2001).

23 Bichsel, Conflict Transformation in Central Asia.

24 Gordon White, "Civil Society, Democratization and Development (I): Clearing the Analytical Ground," Democratization 1, no. 2 (1994): 375-390; Sunil Khilnani, "The Development of Civil Society," in Civil Society: History and Possibilities, ed. Sudipta Kaviraj and Sunil Khilnani (Cambridge: Cambridge University Press, October 2001), 12.

25 Megoran, "Calming the Ferghana Valley Experts," 25. 
cultivation. ${ }^{26}$ Located in the northwest of Tajikistan, Sughd is home to nearly $2,349,000$ inhabitants and has the largest proportion of cultivated land in the republic, in addition to being the only region of Tajikistan fully dependent on external sources of water. ${ }^{27}$

Of the 971-kilometre border dividing Kyrgyzstan and Tajikistan, only 519 kilometers have been officially agreed upon. ${ }^{28}$ The disputed sections that separate the two states run through Kyrgyzstan's Batken and Tajikistan's Sughd provinces. There are also two enclaves, the Tajik districts of Vorukh and Western Qalacha, which are located within the Batken region. These are the areas which see periodic conflict incidents involving civilians, security forces and state officials. More specifically, the southern part of Isfara district of the Sughd region (Chorkuh, Surkh, Shurab and Vorukh jamoats ${ }^{29}$ ) and the western part of the Batken region (Ak-Sai, Samarkandek and Ak-Tatyr municipalities) are the areas identified by observers as the most prone to inter-ethnic tensions. ${ }^{30}$

In general, the years of independence for both Kyrgyzstan and Tajikistan have been marred by conflicts on the borders of their Batken and Sughd provinces, respectively (for instance, in 2000, 2003, 2005, 2008, 2011, 2014, 2015). Per some reports, in the period from 2011 to 2013, there were 63 incidents on the Kyrgyz-Tajik border, ranging from small fights to hostage taking. ${ }^{31}$ Serious conflict escalations usually involved arson, stone-throwing and the usage of garden tools. As a result, such escalations were often labelled as "ketmen wars." 32

The conflict of January of 2014, however, was marked by a new dynamic. The Kyrgyz government began constructing an alternative road along KokTash-Ak-Sai-Tamdyk, which would bypass the Tajik enclave of Vorukh. On January 11, soldiers of the Tajik Border Guard Service arrived on a construction

26 National Statistical Committee of the Kyrgyz Republic, "Chislennost naseleniya Kirgizskoi Respubliki za 1 Janvarya 2016 goda (Population of the Kyrgyz Republic for 1 January 2016)," 2016, http://stat.kg/ru/statistics/naselenie/.

27 Asel Murzakulova and Irène Mestre, Natural Resource Management Dynamics in Border Communities of Kyrgyzstan and Tajikistan, Research Report (Bishkek: University of Central Asia, 2015), 7.

28 David Trilling, “Kyrgyzstan-Tajikistan: What's Next After Border Shootout?" Eurasianet.org, January 13, 2014, http://www.eurasianet.org/node/67934; "Kabmin odobril delimitaciu $519 \mathrm{~km}$ granicy s Tajikistanom (Government Approved the Delimitation of a 519-km Border with Tajikistan," Sputnik, January 16, 2016, https://ru.sputnik.kg/ politics/20160116/1021605681.html.

29 In Tajikistan, a jamoat is an administrative division, a municipality.

30 Bichsel, Conflict Transformation in Central Asia, 103.

31 Abdulkholiq Kholiqi and Nabijon Rahimov, "Disputable Territories as Hotbeds of Tension on the Border," Bulletin of TSULBP (2015): 188-196.

32 Bichsel, Conflict Transformation in Central Asia. 'Ketmen' is a garden tool. 
site and confronted workers laying the road. ${ }^{33}$ In the ensuing standoff Kyrgyz and Tajik border guards fired shots. As a result, 5 Kyrgyz soldiers and 3 Tajik solders were injured. ${ }^{34}$ The Ministry of Foreign Affairs of Tajikistan insisted that a stretch of the bypass road was going through a contested plot of land, and thus the Tajik border guards had the right to block the construction. ${ }^{35}$ The Kyrgyz side insisted that the road was going through Kyrgyz territory and was built to ensure the secure and independent movement of Kyrgyz citizens who otherwise had to pass through Vorukh. ${ }^{36}$

If previous escalations were "ketmen wars" or clashes, involving civilians equipped with stones and garden tools, this conflict involved regular army units from both sides who allegedly used heavy weapons such as mortars and rocket-propelled grenades. ${ }^{37}$ This menacing trend has prompted the governments of Kyrgyzstan and Tajikistan to sit down again at the negotiating table and devise solutions addressing the root causes of the problem. ${ }^{38}$

Nonetheless, despite the ongoing inter-governmental discussions on the need to mitigate tensions on the Kyrgyz-Tajik borders, incidents of sporadic violence and escalations thereof have not diminished. Two months after the meeting of the intergovernmental commission, on May 7, 2014, clashes involving nearly 1,500 people broke out again on the Kyrgyz-Tajik border, leaving several people injured in addition to burned out cars and a gas station. ${ }^{39}$ Only recently,

33 "Kto pervim otkril ogon na tajiksko-kirgizskoi granitce? (Who Opened Fire First on the Kyrgyz-Tajik Border?)," Asia-Plus, January 11, 2014, https://news.tj/ru/news/ktopervym-otkryl-ogon-na-tadzhiksko-kyrgyzskoi-granitse.

34 "Stroitelstvo dorogi Ak-Sai-Tamdyk-Kok-Tash prodoljaetsya (Construction of the Road Ak-Sai-Tamdyk-Kok-Tash Continues)," Azattyk, January 12, 2014, http://rus.azattyk.org/a/25227290.html.

35 "Kto pervim otkril ogon na tajiksko-kirgizskoi granitce? (Who Opened Fire First on the Kyrgyz-Tajik Border?)."

36 "Uchastok v 0.78 sotok na trasse Kok-Tash-Aksai-Tamdyk, kotoryi osparival Tajikistan prinadlezhit Kyrgyzstanu - A. Mamataliev (The plot of land of 0.78 acres on the road Kok-Tash-Aksai-Tamdyk disputed by Tajikistan belongs to Kyrgyzstan - A. Mamataliev)," Kabar, May 12, 2014, http://old.kabar.kg/rus/society/full/79246; "Stroitelstvo avtodorogi Kok-Tash-Ak-Sai-Tamdyk budet dovedeno do konca (The construction of the road Kok-Tash-Ak-Sai-Tamdyk will be completed)," Knews, January 12, 2014, http://knews.kg/2014/01/stroitelstvo-avtodorogi-kok-tash-ak-saytamdyik-budet-dovedeno-do-kontsa/.

37 "Kto pervim otkril ogon na tajiksko-kirgizskoi granitce? (Who Opened Fire First on the Kyrgyz-Tajik border?);" Timur Toktonaliev, Lola Olimova, and Nazarali Pirnazarov, "Kyrgyz-Tajik Row After Border Clash" (Institute for War and Peace Reporting, 15 January 2014), https://iwpr.net/global-voices/kyrgyz-tajik-row-after-border-clash.

38 "Kyrgyzstan-Tajikistan: Chego ozhidat ot peregovorov? (Kyrgyzstan-Tajikistan: What to Expect from the Negotiations?)," Azattyk, January, 13, 2014, http://rus.azattyk.org/a/25228797.html.

39 "GPS soobshaet podrobnosti incidenta na kyrgyzko-tajikskom uchastke granitsy v Batkenskom raione (State Border Service Reports the Details of the Incident on the Kyrgyz-Tajik Border in the Batken Region)," Turmush, May 8, 2014, http://www.turmush.kg/ru/news:57661; "Zamglavi MVD K. Asanov posetil zhitelei 
on January 22, 2017, dozens of young men from both sides clashed near KokTash village. ${ }^{40}$ As Abdulkholiq Holiki and Nabijon Rahimov advised, ${ }^{41}$ the latent Isfara-Batken conflict inherited from the Soviet past is still haunting modern Kyrgyzstan and Tajikistan, thus hindering economic and cultural cooperation, complicating interstate relations and taking lives of civilians.

\section{Causes of Conflict}

As identified earlier, from the late 1990s international aid agencies advanced a wide range of conflict prevention activities in the Ferghana Valley under the tenets of promoting 'liberal peace.' Most of them perceived conflict as resultant from disputed borders, scarce natural resources, economic underdevelopment and unsatisfied human needs. A more detailed scrutiny of the BatkenIsfara tensions revealed that escalations in the region were also related to the Soviet past and a lack of evidence-based policy advice in addition to the inefficient use of natural resources and militarization of borders.

\section{Soviet Legacy}

Although modern Kyrgyzstan and Tajikistan have witnessed a rise of conflict escalations on their borders, such conflict trends are not exclusive to the period of their independence. During the Soviet period the region also witnessed a number of conflict escalations despite the prevailing assumptions that territorial conflicts in Central Asia are inherently a post-Soviet phenomenon.

In 1924, after the initial Soviet national-territorial delimitation, the Kyrgyz Autonomous Soviet Socialist Republic (ASSR) requested the Soviet central government to assign Isfara and Sokh administrative units to the Kyrgyz ASSR. ${ }^{42}$ Based on the evaluation of inter-republican commissions, the central government rejected the petitions of the Kyrgyz ASSR and ruled that Isfara and Sokh would remain within the jurisdiction of the Uzbek Soviet Socialist Republic

sel Batkenskogo raiona, gde vo vremya prigranichnogo incidenta bili sozhzheni ryad ob'ektov (Deputy Head of the Ministry of Interior Affairs K. Asanov Visited the Villagers of the Batken Region, Where Several Objects Have Been Burned Down During the Cross-border Conflict)," Turmush, May 15, 2014, http://www.turmush.kg/ru/news:58559; Mark Vinson, "Border Clashes With Kyrgyzstan Threaten Tajikistan's Regional Integration," Eurasia Daily Monitor 11, no. 94 (20 May 2014), https://jamestown.org/program/border-clashes-withkyrgyzstan-threaten-tajikistans-regional-integration/.

40 Bakyt Tolkanov, "Obe storoni kinflikta na kyrgyzsko-tajikskoi granitse - o chem govoryat (Two Sides of Conflict on the Kyrgyz-Tajik Borders - What They Are Talking About)," Sputnik, January 23, 2017, https://ru.sputnik.kg/analytics/20170123/ 1031403221/chto-proizoshlo-na-granice-kyrgyzstana-i-tadzhikistana.html.

41 Kholiqi and Rahimov, "Disputable Territories as Hotbeds of Tension on the Border."

42 Arslan Koichiev, "Ethno-Territorial Claims in the Ferghana Valley During the Process of National Delimitation, 1924-7," in Central Asia: Aspects of Transition, ed. Tom Everett-Heath (London: Routledge Curzon, 2003), 45-46; Bichsel, Conflict Transformation in Central Asia. 
(SSR). ${ }^{43}$ Although the Soviet central government declared that nationalterritorial delimitation in the Ferghana Valley was "decisively settled," both the Kyrgyz ASSR and the Uzbek SSR disputed the final settlement.

As a result, regional territorial disputes were suspended, while an administrative borderline was often not enforced. ${ }^{44}$ Nonetheless, from time to time the region of Batken and Isfara turned violent over land plots. ${ }^{45}$ For instance, in 1936, violence between nomadic Kyrgyz and sedentary Tajik people over a winter encampment in the area of the Vorukh enclave resulted in the deaths of several people and left numerous others injured.

In the late 1960s, a cultivation farm of the Isfara region began expanding onto pastures of a state farm of the Batken region. Although the Soviet Ministry of Agriculture allowed the Isfara collective farm to use the land as pastures, under pressure from rapid population growth the Isfara farm decided to build a canal on this land to extend the irrigated area beyond the hitherto cultivated land. ${ }^{46}$ The aggrieved Kyrgyz villagers appealed on various instances, including sending a petition to the central government. ${ }^{47}$ After receiving no proper response from the authorities, Kyrgyz villagers decided to intervene themselves, which led to violent escalations between Kyrgyz and Tajik villagers in 1969, 1970 and 1975.

After the escalation of 1975 the inter-republican commission resolved to divide the disputed land between the two farms and resettle the Kyrgyz people to the newly-established village of Ak-Sai. ${ }^{48}$ The commission also obliged the Isfara farm to provide the Batken farm with water during the irrigation periods. However, this prescription was not sustained, because the water from the Mekhnatobod-Ak-Sai canal barely fulfilled the needs of the Vorukh community. ${ }^{49}$ As a result, under pressure from the aggrieved Kyrgyz villagers, the Kyrgyz SSR decided to construct a pump station of its own to satisfy the needs of the Ak-Sai community.

In 1989, a dispute over a land plot between the villages of Uch-Dobo and Khodjai Alo escalated into a violent conflict involving the villagers of Vorukh and Ak-Sai. ${ }^{50}$ Allegedly, the Tajik villagers had attempted to extend their culti-

43 The Tajik ASSR was an autonomous republic within the Uzbek SSR.

44 Koichiev, "Ethno-Territorial Claims in the Ferghana Valley."

45 Bichsel, Conflict Transformation in Central Asia.

46 Bichsel, Conflict Transformation in Central Asia.

47 Bichsel, Conflict Transformation in Central Asia.

48 Bichsel, Conflict Transformation in Central Asia; Jamoat Resource Centre of Vorukh, "Potential for Peace and Threats of Conflict: Development Analysis of Cross-border Communities in Isfara District of the Republic of Tajikistan and Batken District of the Kyrgyz Republic" (2011).

49 Bichsel, Conflict Transformation in Central Asia.

50 Bichsel, Conflict Transformation in Central Asia; Jamoat Resource Centre of Vorukh, "Potential for Peace and Threats of Conflict"; Tokhir Safar, "Vesna - goryachaya pora dlya tajiksko-kirgizkih otnosheni? (Spring - Is It a Hot Season for the Tajik-Kyrgyz 
vations towards Kyrgyz pastures, but after being met with resistance from the Kyrgyz villagers they blocked the Ak-Tatyr canal, which provided water to the Kyrgyz downstream villages. The Kyrgyz villagers attempted to forcibly unblock the canal which in turn was met with violent resistance from the Tajik villagers. The violence between the villagers was halted only after the intervention of Soviet soldiers. ${ }^{51}$

A brief overview of conflict escalations in the Batken-Isfara region during the Soviet period reveals that the conflictual dynamics in this part of the Ferghana Valley have not emerged as a new phenomenon exclusive to the period of post-Soviet state building, and that incidents of conflict escalations were recorded as early as in the 1930s. The nature of these conflicts reveals that the Soviet central government had a clear preference to a sedentary lifestyle and agricultural modes of production over a transhumant lifestyle and animal husbandry which, in turn, accounts for most of the conflict history in the BatkenIsfara region. ${ }^{52}$ In an attempt to secure Soviet self-sufficiency, Moscow focused on increasing arable land for agriculture, even at the expense of pastures. Soviet modernization projects not only affected nomadic and semi-nomadic populations and the long-established lifestyles in Central Asia, but also paved the way for environmental catastrophes such as the depletion of the Aral Sea. In turn, the failures of the Soviet government to address the unintended repercussions of its policies turned the Batken-Isfara region into a site of contestation that divided sedentary Tajiks and transhumant Kyrgyz.

\section{Inefficient Use of Natural Resources}

Many observers have underlined that the real causes of conflict, which divide Batken and Isfara communities on ethnic lines, are rooted in the scarcity of natural resources. In particular, water is perceived to be a cause of conflict. There is a plethora of literature, however, which advises that causality between water and conflict is difficult to validate. ${ }^{53}$ On the contrary, even if conflict is already waged over other issues, shared interests along waterways consistently outweigh conflict-inducing characteristics, while cooperative water regimes tend to be particularly resilient over time. ${ }^{54}$

Nonetheless, there is a recurring discourse that the tensions on the BatkenIsfara border segment are directly linked to water scarcity, although this asser-

Relations?)," Radio Free Europe, March 24, 2011, http://www.ozodi.org/a/chorkuh_ isfara_kyrgyzstan/2348352.html.

51 Bichsel, Conflict Transformation in Central Asia.

52 Bichsel, Conflict Transformation in Central Asia.

53 William Mitchell, "The Hydraulic Hypothesis: A Reappraisal," Current Anthropology 14, no. 5 (December 1973): 532-534; Hans P. W. Toset, Nils P. Gleditsch, and Håvard Hegre, "Shared Rivers and Interstate Conflict," Political Geography 19, no. 8 (2000): 971-96.

54 Aaron T. Wolf, "Conflict and Cooperation along International Waterways," Water Policy 1, no. 2 (1998): 251-65. 
tion fails to withstand more detailed scrutiny. According to the AQUASTAT of the Food and Agriculture Organization (FAO) of the United Nations, total per capita amounts of renewable water resources in Kyrgyzstan $\left(4,336.00 \mathrm{~m}^{3}\right)$ and Tajikistan $\left(3,095.00 \mathrm{~m}^{3}\right)$ are higher than those of China $\left(2,051.00 \mathrm{~m}^{3}\right)$, Czech Republic $\left(1,245.00 \mathrm{~m}^{3}\right)$, Spain $\left(2,384.00 \mathrm{~m}^{3}\right)$, France $\left(3,325.00 \mathrm{~m}^{3}\right)$ and Germany $\left(1,878.00 \mathrm{~m}^{3}\right)$. The difference between fresh water and agricultural water withdrawals as a percentage of total renewable water resources in Kyrgyzstan and Tajikistan is significant, but not critical. In their study, Asel Murzakulova and Irene Mestre ${ }^{55}$ applied the Falkenmark indicator to Kyrgyzstan and Tajikistan, which uses a threshold of $1,700 \mathrm{~m}^{3}$ per capita per year to determine if a population is under water stress. Accordingly, both countries do not fall into the category of states under water stress and are well resourced with water. Bichsel ${ }^{56}$ goes even further to argue that the whole notion of scarcity is a relative concept constituted by the social relations, political interests and moralities that shape the access to, control over and struggle for natural resources, and thus it should not be detached from the specific political, historic and cultural context.

In other words, water scarcity in Central Asia is defined by the use of water rather than by its real amount. As aforementioned, the policies of the Soviet central government favored a sedentary lifestyle and agricultural modes of production; however, water was not effectively managed during the Soviet times neither, while irrigation channels were in a poor state even before the 1990s. During the period of independence, water infrastructure has only deteriorated further, since the budgets of both governments and farms have fallen dramatically. ${ }^{57}$ Complex hydraulic infrastructure systems inherited from the Soviet Union assumed cooperation between the Central Asian states, especially between the upstream and downstream states. Nonetheless, the unified position of the USSR has been long replaced by sharply divergent economic interests and security arrangements, corresponding to the different strategic views of the Central Asian leadership.

As a result, the current water infrastructure on the Kyrgyz-Tajik border has fallen into a state of disrepair. Water channels are either silted up or damaged, while water pumps are broken or not working at full capacity, all of which leads to further water losses. Since hydraulic infrastructure is transboundary in nature, there is no dedicated institution responsible for its rehabilitation and maintenance, while neither the government of Kyrgyzstan nor that of Tajikistan is willing to invest in water systems beyond its own national borders.

Accordingly, tensions on the border areas of Batken and Isfara escalate when the irrigation season starts. The cooperative expectations quite often do

55 Murzakulova and Mestre, Natural Resource Management Dynamics in Border Communities of Kyrgyzstan and Tajikistan.

56 Bichsel, Conflict Transformation in Central Asia.

57 Lisa Marie Izquierdo, Mari Stangerhaugen, Diana Castillo, Robert Nixon, and Gloria Jimenez, Water Crisis in Central Asia: Key Challenges and Opportunities (New York: New School University, December 2010). 
not match the reality both at inter-state and local levels. Even though the area is not under water stress, downstream users are still often deprived of water, while upstream users often abuse water abstractions. In turn, downstream users seek to mitigate this unequal arrangement through negotiations, protests, obstructions and sabotage, which in turn increase the security dilemma and escalate tensions.

\section{Militarization of Borders}

In the early August of 2015, a thin lane separating Kyrgyzstan and Tajikistan became a zone of conflict between the citizens of both countries. Different sources quote up to 200 people involved from each side in a two-day rockthrowing incident. ${ }^{58}$ According to the account of the Kyrgyz side, Tajik citizens blocked a road to a cemetery used by both the Kyrgyz villagers of Kok-Tash and the Tajik villagers of Somonien. In response, the residents of Kok-Tash blocked a water canal supplying Somonien. According to the account of the Tajik side, these events took place in the reverse order. While the social fabric in these villages was restored promptly, such incidents serve to expose how minor violations of unwritten rules have the potential of sparking violent conflicts. ${ }^{59}$

Most observers refer to a border demarcation as a solution that will ease such tensions on the Kyrgyz-Tajik borders. Indeed, for over 25 years Tajikistan and Kyrgyzstan could not agree on border delimitation and demarcation. The map of the Ferghana Valley is marked by disputed and porous borders and territorial units, known as 'enclaves,' which are separated from its mainland by the lands of other countries. It appears that such divisions aggravate existing water and land disputes and fuel further economic uncertainties and interethnic animosities.

As aforementioned, soon after the collapse of the USSR, the Ferghana Valley was discursively cast as a volatile and crisis-ridden region prone to sectarian violence. These assumptions were based on the normative idea that the conception of territorial ambiguity is a metonym for latent conflict and danger to united citizenry. ${ }^{60}$ As a result, those discourses characterized Central Asia as a site of intervention, prompting the international community to enter the region to mitigate conflict potential and promote peaceful development. However,

58 Peter Leonard, "Tajikistan \& Kyrgyzstan: Interethnic Clash Shines Light on Fraying Social Fabric," Eurasianet, August 11, 2015, http://www.eurasianet.org/node/74631; "Konflikt mezdhu grazhdanami Kyrgyzstana i Tajikistana v sele Kok-Tash (Conflict between the citizens of Kyrgyzstan and Tajikistan in the village of Kok-Tash)," Sputnik, August 4, 2015, https://ru.sputnik.kg/infographics/20150804/10171663 13.html; Mariya Zozulya, "Na granice Batkenskoi oblasti i Tajiksitana proizoshel conflikt (A conflict took place on the border of the Batken region and Tajikistan)," Vechernii Bishkek, August 3, 2015, http://www.vb.kg/doc/321945_na_granice_ batkenskoy_oblasti_i_tadjikistana_proizoshel_konflikt.html.

59 Leonard, "Tajikistan \& Kyrgyzstan."

60 Reeves, "Locating Danger." 
quite often, those investments did not translate into calm and peaceful borders. $^{61}$

One of the greatest misconceptions of national and international observers was that stricter border control would mitigate the conflict potential of the region. While the fortification of border services and infrastructure may be a prerequisite for the modern nation-state, the fortification of yet unsettled border segments may emerge as a challenging step to introduce. As Bichsel ${ }^{62}$ highlighted, in the case of the Batken-Isfara region, border posts and checkpoints have only served to aggravate existing tensions. The region, where different ethnic groups have long co-existed in a network of interdependent communities, needed a more sensitive and human approach. As Madeleine Reeves ${ }^{63}$ underlined, the assertion of state territoriality in the Ferghana Valley often cuts across lines of kinship, worship, friendship, work, and trade.

Rather than repairing, barbed wire fencing, passport checks, and bypass roads only dent the existing microcosms further. ${ }^{64}$ This phenomenon explains why, for instance, the bypass road, known locally now as "the Kyrgyz road," has emerged as a cause of rupture between the Kyrgyz and Tajik villages. The application of state territoriality has excluded Tajik communities from using previously shared spaces. As a result, aggrieved Tajik youth have been known to pelt bypassing cars with stones, which in turn leads to retaliatory measures from drivers and an escalation of the situation.

Anna Matveeva ${ }^{65}$ identified borders as places, where communities project their fears onto each other, whether these are the fears of being encircled and trapped or the fears of losing territory, assets and resources. In a sense, fear becomes a catalyst for identity formation in cross-border communities: it fortifies perceptions of collective insecurity even during periods of tranquility and fosters the emergence of strong ethnic borderland identities reinforced by new nationhood ideologies and "us against them" associations. ${ }^{66}$ In turn, even petty disputes in Central Asia can acquire a feature of ethnic polarization. ${ }^{67}$

That said, it is not porous borders that escalated conflict in the BatkenIsfara area, but rather it has been the greater focus on security through the militarization of borders that has transformed the nature of relations in the region. Strict border regimes often contribute to instability instead of strengthening fragile peace by hampering cross-border movement across invisible fron-

61 D.T., "Enclaves in Central Asia: The Post-imperial Chessboard," The Economist, April 1, 2014, www.economist.com/banyan/2014/04/02/the-post-imperial-chessboard.

62 Bichsel, Conflict Transformation in Central Asia.

63 Madeleine Reeves, Border Work: Spatial Lives of the State in Rural Central Asia (Ithaca, NY: Cornell University Press, 2014).

64 Reeves, Border Work.

65 Anna Matveeva, "Divided we fall ... or rise? Tajikistan-Kyrgyzstan border dilemma," Cambridge Journal of Eurasian Studies 1 (2017): 1-20.

66 Matveeva, "Divided we fall ... or rise?"

67 Matveeva, "Divided we fall ... or rise?" 
tiers that have been long governed by established rules, traditions and history. During the Soviet times, the borders, which separate modern Kyrgyzstan and Tajikistan, had divided two Soviet socialist republics administratively. Accordingly, the rules and arrangements that governed the transboundary relations of two Soviet republics were not as strict as those that applied to the neighbors of the USSR. However, these practices changed in the early 1990s, as the internal administrative borders that separated the communities of Batken and Isfara suddenly re-emerged as international borders that thereafter separated "us" from "them."

For this reason, a stricter border regime in Central Asia does not necessarily embody a more peaceful social fabric. The involvement of border guards and the use of military hardware are more likely to escalate the conflict to a completely new level - to the extent that one could even reconsider the plausibility of the aforementioned 'catastrophizing' writings. As the conflict near Vorukh in May 2014 served to show, this was no longer a "ketmen fight," as it involved regular army units, heavy weapons and diplomatic protest notes. As Jeremy Slack and co-authors emphasized, for many politicians 'secure' means 'militarized,' which is not true for the people living on the borders. ${ }^{68}$ For instance, harassment perpetrated by border and immigration agents contradicts and often violates the notion of "human security." 69

Accordingly, it is not the disputed and porous borders that drive the conflict in the Batken-Isfara area, but rather the 'securitization' of border relations that aggravates existing disputes and fuels further uncertainties and animosities. Instead of diminishing the number of "ketmen fights," the militarization of borders escalates the tensions stalling any further progress to a peaceful resolution of local disputes.

\section{Lack of Evidence-Based Policy Advice}

The ineffective use of natural resources or the militarization of borders quite often stem from a lack of evidence-based decision-making in the region. Although evidence-based policymaking is predominantly well established in the developed world, Central Asian states are yet to fully experience the benefits of informed decision-making. Such an approach assumes the application of systematic evidence in order to continually improve policy decisions. Policymaking, derived from quality research and applied analyses, is instrumental in producing better policy options, reducing poverty, stimulating economic growth, and enhancing the quality of life.

68 Jeremy Slack, Daniel E. Martinez, Alison Elizabeth Lee, and Scott Whiteford, "The Geography of Border Militarization: Violence, Death and Health in Mexico and the United States," Journal of Latin American Geography 15, no. 1 (March 2016): 7-32.

69 Mary Kaldor, Mary Martin, and Sabine Selchow, "Human Security: A New Strategic Narrative for Europe," International Affairs 83, no. 2 (March 2007): 273-88; Slack, Martinez, Lee, and Whiteford, "The Geography of Border Militarization." 
However, institutional capacity to conduct sustained and policy-relevant research is weak across the region. One of the main factors contributing to the pervasive capacity gap in public administration and applied research is the overall lack of investment in professional development opportunities for civil servants and researchers. The collapse of the USSR and the subsequent decline of its educational institutions along with a lack of national funding to sponsor quality research eroded the capacity of the Central Asian states to conduct evidence-based analyses. In addition, the interest of the international academic community in Central Asia (compared to that of the early 1990s) has also decreased significantly.

As a result, since governments, international donors, and civil society actors often lack access to sufficiently well-founded options to inform robust policy debates and sound decisions, certain policy choices are detached from the actual context on the ground, do not address the root causes of the problem and at worst only exacerbate situations.

For instance, Murzakulova and Mestre ${ }^{70}$ advised that due to public administration reforms pasture lands in Kyrgyzstan and Tajikistan are managed by diverse institutions with different interests and priorities such as pasture users' unions, state forestry administrations, and collective and individual farms. Such fragmentation complicates the processes of effective pasture management. In fact, the current Land Code of Kyrgyzstan prohibits the lease of pastures. This legislature, introduced to mitigate pasture degradation, however, is not conducive to mitigating the conflict potential of the Batken-Isfara region. On the contrary, Tajik communities often pay bribes for illegal grazing, which not only increases potential points of friction between Tajik villagers and Kyrgyz border guards, but can also trigger grievances among the Kyrgyz communities. ${ }^{71}$

In addition, the underreported livestock of the Kyrgyz villagers who also use the same pastures as Tajik villagers contributes to an increasing pressure on land and a faster degradation of pastures, which may lead to new conflicts over access to lands in the future. The Jamoat Resource Centre of Vorukh ${ }^{72}$ reports that occasionally Tajik shepherds who have to pass through the Kyrgyz territory to reach remote Tajik grazing territories fail to pass "environmental checkpoints" and are subject to money extortions from border guards, police, and even youth gangs. As a solution, Tajik villagers often hire Kyrgyz shepherds to ease the transit. However, the potential losses of Tajik livestock also lead to disputes, since there is usually no written agreement between the Tajik owners of livestock and the Kyrgyz shepherds.

70 Murzakulova and Mestre, Natural Resource Management Dynamics in Border Communities of Kyrgyzstan and Tajikistan.

71 Jamoat Resource Center of Vorukh, "Potential for Peace and Threats of Conflict: Development Analysis of Cross-border Communities in Isfara District of the Republic of Tajikistan and Batken District of the Kyrgyz Republic" (2011).

72 Jamoat Resource Centre of Vorukh, "Potential for Peace and Threats of Conflict." 
Accordingly, evidence-based policymaking has the potential to improve the quality of life in the Batken-Isfara region. Evidence-based policymaking concerns the process of devising policy. This process should be rational and rigorous and grounded in the best available, contextual, and experiential evidence. In fact, building effective, efficient and accountable institutions on both national and subnational levels has been identified by the United Nations as one of the most paramount goals to be achieved within the framework of the 2030 Agenda for Sustainable Development. Such an informed approach may not only help mitigate cross-border tensions, but also help to address a wider range of structural problems prevailing in the region.

\section{Threats of Radical Islamism}

There is a popular discourse both within and outside of the region that Muslim radicalization is rapidly taking place across Central Asia. The widespread view is that the region is harboring violent religiously-motivated extremism. Recently, the International Crisis Group (ICG) ${ }^{73}$ reported that the Islamic State (IS) is attracting a coalition of Central Asian jihadists and sympathizers and fostering a network of links within the region and nearby areas, including the Caucasus and Xinjiang. Violent extremist groups are gaining renewed traction, while Central Asian governments are using these threats to support their own political agendas and to curtail civil liberties.

As ICG concluded, ${ }^{74}$ the environment in Kyrgyzstan and Tajikistan is favorable for radical groups with violent agendas to establish their strongholds. Poverty, ethnic divisions, state weaknesses and persistent corruption, among many other factors, draw some economically and socially marginalized Kyrgyz, Tajiks and Uzbeks to more radical and externally sponsored Islam. According to ICG interlocutors, Hizb ut-Tahrir already has thousands of members in Kyrgyzstan who are connected to the Islamic Movement of Uzbekistan (IMU) and the IS.

Indeed, at first glance, it may appear that the application of such discourse to the Batken-Isfara region may be quite relevant. In 1999 and 2000, the south of Kyrgyzstan was invaded by militant pan-Islamist extremists of the IMU led by Juma Namangani. Several hundred guerrillas wreaked havoc in the Batken re-

73 International Crisis Group, "Syria Calling: Radicalisation in Central Asia," Europe and Central Asia Briefing no. 72 (Bishkek/Brussels: Crisis Group, 20 January 2015), accessed May 18, 2018, https://www.crisisgroup.org/europe-central-asia/centralasia/syria-calling-radicalisation-central-asia.

74 International Crisis Group, "Kyrgyzstan: State Fragility and Radicalization," Europe and Central Asia Briefing no. 83 (Osh/Bishkek/Brussels: Crisis Group, 3 October 2016), accessed May 18, 2018, https://www.crisisgroup.org/europe-centralasia/central-asia/kyrgyzstan/kyrgyzstan-state-fragility-and-radicalisation; International Crisis Group, "Tajikistan Early Warning: Internal Pressures, External Threats," Europe and Central Asia Briefing no. 78 (Bishkek/Brussels: Crisis Group, 11 January 2016), accessed May 18, 2018, https://www.crisisgroup.org/europe-centralasia/central-asia/tajikistan/tajikistan-early-warning-internal-pressures-externalthreats. 
gion, terrorizing villagers and taking hostages including high-ranking Kyrgyz officials and Japanese geologists. Nearly 60 people were killed on the Kyrgyz side during the fights with militant extremists in 1999 and 2000. Although such extremist incursions have not taken place since in Kyrgyzstan, ICG warns that the IMU has a sleeping presence in southern Kyrgyzstan, while some of its members have emerged recently as recruiters for those Central Asians who want to go to Syria. ${ }^{75}$

Nonetheless, despite the daunting predictions that the region is falling into the abyss of radical Islamism, there is little evidence at this stage to support the idea that Central Asia is being significantly infiltrated by violent Islamic extremist organizations. ${ }^{76}$ John Heathershaw and David Montgomery ${ }^{77}$ argue that the threat of violent extremism in the region is both of a lower magnitude and different form than that identified in the public discourses, in that it is isolated, localized and inhibited by secularization as much as it is driven by radicalization. In the period between 2001 and 2013, there were only three attacks in Central Asia that have been claimed by violent Islamic groups (with a total of 11 deaths), while out of the 51 organizations on the US State Department's Designated Foreign Terrorist Organizations list only two-the IMU and the Islamic Jihad Union-have any links to Central Asia.

In an open letter to ICG concerning its reporting of Islamic radicalization in Central Asia, a group of Central Asia scholars stressed that ICG's "specious and methodologically weak conclusions" can lead to a series of mistaken assumptions, problems, and solutions in the reactive policy environment of Central Asia. ${ }^{78}$ The signatories of this letter underlined that there is no link between poverty and low education levels and a desire to join violent extremist groups, as well as the growth of non-traditional religious groups is not an indicator of the growth of violent extremism. The academics denote that such unsupported claims along with the absence of rigorous methodology influence policy and decision-makers in government and international organizations to believe in the existence of an imminent security threat from Islam and devise rapid responses in the form of a security policy on religion.

ICG immediately responded by welcoming an exchange of views and ideas in order to better understand the specific and multiple factors that can lead to radicalization. The very existence of such conflicting approaches to understanding Islamic radicalization in Central Asia demonstrates that this topic of common concern is extremely contested. There is even no agreement on how many

75 International Crisis Group, "Kyrgyzstan: State Fragility and Radicalization."

76 John Heathershaw and David Montgomery, "The Myth of Post-Soviet Muslim Radicalization in the Central Asian Republics," Research Paper (London: Chatham House/ The Royal Institute of International Affairs, 11 November 2014).

77 Heathershaw and Montgomery, "The Myth of Post-Soviet Muslim Radicalization."

78 An open letter from Central Asia scholars to the International Crisis Group, "Understanding Islamic Radicalization in Central Asia," 2017, http://thediplomat.com/ 2017/01/understanding-islamic-radicalization-in-central-asia. 
Central Asians left for Syria and Iraq to join ISIS. According to the Polish Institute of International Affairs, Central Asia sends far less fighters to Iraq and Syria than the countries of Europe, the Middle East and North Africa. ${ }^{79}$ On a state-bystate basis, 1 in 14,400 Turkmen, 1 in 40,000 Tajiks, 1 in 56,000 Kyrgyz, 1 in 58,000 Uzbeks, and 1 in 72,000 Kazakhs have become foreign fighters in Syria. ${ }^{80}$

The Polish Institute of International Affairs reports that in some countries of the Middle East and North Africa these numbers are more staggering. For example, 1 in 6,500 in Lebanon, 1 in 5,300 in Jordan, 1 in 7,300 in Tunisia, 1 in 18,200 in Saudi Arabia, and 1 in 22,000 in Morocco have joined foreign fighter ranks in Syria and Iraq. In Europe, 1 in 11,700 in Bosnia and Herzegovina, 1 in 23,800 in Belgium, and 1 in 55,200 in France have gone to fight for Islamic radicals in Syria and Iraq. ${ }^{81}$

Yet, despite the assertive claims of the Polish Institute of International Affairs, the range in the estimates of the actual Central Asian recruits varies significantly. Indira Zholdubayeva, the Prosecutor General of the Kyrgyz Republic, reported that there are approximately 500 Kyrgyz citizens fighting in Syria and that another 500 Kyrgyz citizens affiliated with terrorist organizations were uncovered by Kyrgyz secret services. ${ }^{82}$ The State Committee for the National Security of the Kyrgyz Republic also confirmed that approximately 400 Kyrgyz nationals are currently in Syria, 60 more returned to Kyrgyzstan and were prosecuted, and 51 people were killed in Syria. ${ }^{83}$ In Tajikistan, official reports estimate that up to 700 Tajik citizens joined ISIS in Syria. ${ }^{84}$ The Ministry of Interior Affairs of Tajikistan stated that according to its information there are 1,100 citizens of Tajikistan fighting for ISIS in Syria and Iraq..$^{85}$

However, the relatively low interest amongst Central Asians to join radical Islamic organizations does not render the problem obsolete. Recent terrorist attacks in a shopping district of Stockholm, at Istanbul's Reina nightclub and in a Saint Petersburg metro station threw Central Asian natives in a notorious

79 Anna Dyner, Arkadiusz Legieć, and Kacper Rękawek, "Ready to Go? ISIS and Its Presumed Expansion into Central Asia," Policy Paper no. 19(121) (Warsaw: The Polish Institute of International Affairs, June 2015), www.pism.pl/files/?id_plik=20020.

80 Dyner, Legieć, and Rękawek, "Ready to Go?"

81 Dyner, Legieć, and Rękawek, "Ready to Go?"

82 Ekaterina Ivashenko, "Kyrgyzstan: Kto uezjaet voevat v Sirii (Kyrgyzstan: Who goes to fight in Syria)," Fergana News, November 20, 2015, http://www.fergananews.com/ articles/8774.

83 Ivashenko, "Kyrgyzstan: Who goes to fight in Syria."

84 Zinaida Burskaya, "Tajikistan, Rossiya, dalee IGIL (Tajikistan, Russia, and then ISIS)," Current Time, December 22, 2015, http://www.currenttime.tv/a/27442533.html.

85 Sairakhmon Nazriev, "Glava Hatlona obespokoen bolshim kolichestvom bokhtarcev v Sirii (Head of Hatlon is concerned with a large number of bokhtars in Syria)," AsiaPlus, January 21, 2017, https://news.tj/ru/news/tajikistan/security/20170121/glavahatlona-obespokoen-bolshim-kolichestvo-bohtartsev-v-sirii. 
spotlight; ${ }^{86}$ and although it is nearly impossible to objectively assess the threats posed by violent extremist organizations to Kyrgyzstan or Tajikistan, existing evidence, albeit scarce, shows that Central Asians do get radicalized and join militant groups in Syria and Iraq. Profiling Tajik fighters in Syria and Iraq, Edward Lemon advised that most of these fighters have been recruited in Russia and transited through Turkey to reach Syria. ${ }^{87}$ However, there is no basic profile that fits all of those who travelled to Syria: some fighters have received formal religious education; some have worked in low-paid jobs; some are highly educated. ${ }^{88}$ Meanwhile, those who travelled to Syria and Iraq include both men and women. In other words, the diverse backgrounds of radicalized Central Asians demonstrate that understanding the causes of radicalization in a single linear way is reductionist and even misleading.

Accordingly, it is too simplistic to assume that villagers of the Isfara and Batken regions are particularly prone to radicalization. Scarce natural resources, economic underdevelopment, disputed borders, and unsatisfied human needs do not necessarily translate into religiously motivated extremism. Yet, Central Asia remains one of the most volatile and vulnerable regions in the world with weak political institutions and poor economic performance. A lack of religious knowledge, social exclusion and the attractiveness of anti-secular political ideas may inspire Central Asians to join violent extremist organizations. As Central Asia scholars advised in their 2017 letter to ICG, ${ }^{89}$ factors that lead to Muslim radicalization are specific, multiple and predominantly non-religious. Thus, a more nuanced and methodologically rigorous approach is needed for understanding this phenomenon and its relevance to regions such as Batken and Isfara.

86 Nick Bailey, "St. Petersburg Subway Bomb: 5 Things to Know About Central Asia," NBC News, April 4, 2017, http://www.nbcnews.com/news/world/st-petersburgsubway-bomb-5-things-know-about-central-asia-n742436; "Turkey nightclub attack: IS says it carried out shooting," BBC News, January 2, 2017, http://www.bbc.com/ news/world-europe-38487509; David Gauthier-Villars and Drew Hinshaw, "Stockholm Attack Puts Focus on Terrorists from Central Asia," The Wall Street Journal, April 9, 2017, www.wsj.com/articles/stockholm-attack-puts-focus-on-terroristsfrom-central-asia-1491764083; Per Nyberg and James Masters, "Sweden Terror Suspect 'Confesses' to Stockholm Attack," CNN, April 11, 2017, accessed May 19, 2018, http://edition.cnn.com/2017/04/11/europe/stockholm-terror-attack-rakhmatakilov/.

87 Edward Lemon, Governing Islam and Security in Tajikistan and Beyond: The Emergence of Transnational Authoritarian Security Governance, PhD dissertation (Exeter, United Kingdom: University of Exeter, 2016).

88 Lemon, "Governing Islam and Security in Tajikistan and Beyond."

89 An open letter from Central Asia scholars to the International Crisis Group, "Understanding Islamic Radicalization in Central Asia." 


\section{Conclusion}

Despite the prevalence of works on conflict in the Ferghana Valley, the literature on conflict potential in the cross-border areas of Kyrgyzstan and Tajikistan is fairly limited. Yet, the number of small-scale clashes and tensions on the borders of the Batken and Isfara regions has been growing steadily. Accordingly, this article sought to contribute to the understanding of the ontology of conflict escalations in the area and identify factors that aggravate tensions between the communities.

A brief overview of conflict escalations in the Batken-Isfara region revealed that cross-border conflict in Central Asia cannot be explained in a single linear way and reduced to a variable of primordial inter-ethnic antagonisms. There are many factors, which can account for sectarian animosities. This article has identified four drivers, which exacerbate tensions and hinder the restoration of a peaceful social fabric in the Batken-Isfara region: the unresolved legacies of the Soviet past, inefficient use of natural resources, militarization of borders, and lack of evidence-based policymaking.

Since this work has been driven by normative aspirations, the author hopes that national actors and the international community will introduce the changes necessary to avert conflicts arising and to turn the Batken-Isfara region into a place free of contestation and hostility. Finally, Central Asian folklore attributes aspects of friendship and hospitality to its peoples. There should be empirical grounds to prove that point.

\section{About the Authors}

Dr. Kemel Toktomushev is a Research Fellow with the University of Central Asia's (UCA) Institute of Public Policy and Administration and an Assistant Professor of Political Science with UCA's School of Arts and Sciences. Toktomushev has extensive experience in both Western and Central Asian environments, and his primary research interests focus on regime security, virtual politics, and the informal political economy of Central Asia. Toktomushev is the author of Kyrgyzstan - Regime Security and Foreign Policy published by Routledge, United Kingdom. Toktomushev holds a PhD in Politics from the University of Exeter and a Master of Science in International Relations from the London School of Economics. He is also a Harvard Kennedy School's Executive Education alumnus.E-mail:kemel_t@yahoo.com. 